\title{
Development of Taxation Practicum Materials Based on Latest Tax Regulations to Increase the Competency of Accounting Students' Departments
}

\author{
Erny Luxy D. Purba ${ }^{1}$, OK Sofyan Hidayat ${ }^{2}$, Cornelius Harefa ${ }^{3}$ \\ \{erny.marcello@gmail.com¹, okdayat4@gmail.com² ${ }^{2}$,harefakornelius@yahoo.com 3 \}
}

Universitas Negeri Medan, Indonesia ${ }^{1,2,3}$

\begin{abstract}
Tax is the biggest source of funding for the state in organizing government. From year to year, revenue from the tax sector continues to show an increase. In the context of efforts to increase tax revenue, the government made a fundamental change by creating a new taxation system, namely by changing the new taxation law. This was done to adjust to the level of social and economic life of the Indonesian people as well as the pace of national development that had been achieved. In addition, the old taxation system has not been able to move the roles of all layers of tax subjects whose role is to produce domestic revenues that are needed to realize the sustainability and increase of national development. The results showed the assessment according to experts of the material is "quite feasible / interesting / motivated" with a score of $83.33 \%$. The results of the assessment according to the design experts are "quite feasible / interesting / motivated" with a score of $80 \%$; while the results of the assessment of media experts are "quite feasible / interesting / motivated" with a score of $79.16 \%$ while the use of teaching material products shows an increase in student learning outcomes, as indicated by the difference in the mean pre-test and post-test scores of small groups is 2.5 and large groups are 2.72 . This means that the use of teaching material products from the development can increase student scores by $25 \%$ and $27.2 \%$, while the results of student assessment of taxation practice modules in small groups are $82.23 \%$ and large groups are $84.57 \%$.
\end{abstract}

Keywords: Teaching Materials, taxation practice, Taxation Regulations, Competence

\section{Introduction}

Tax is the biggest source of funding for the state in organizing government. From year to year, revenue from the tax sector continues to show an increase. In the context of efforts to increase tax revenue, the government made a fundamental change by creating a new taxation system, namely by changing the new taxation law consisting of Law No. 28 of 2007 concerning General Provisions and Methods for Taxation, Law No. 7 of 1983 which was perfected into the Income Tax Law no. 36 of 2008 concerning Income Tax and Regulation of the Minister of Finance Number: 101/PMK.010/2016 concerning the latest PTKP rates as well as Regulation of the Director General of Tax Number PER-32/PJ/2015 concerning PPh 21 rates for Taxpayers (WP) who have a Principal Number Taxpayer (NPWP) and does not have a TIN. UU no. 8 of 1983 which was perfected into Law No. 18 of 2000 concerning Value Added Tax of Goods and Services and Sales Tax on Luxury Goods and PP No. 81/2015 concerning Provisions regarding the types of goods that are exempt from VAT and PP No. 74 of 2015 concerning. Law No. 12 of 1985 which was refined to become Law No. 12 of 1994 
concerning Land and Building Tax, Law No. 13 of 1985 concerning stamp duty and PP No. 23 of 2018 concerning SME Final Income Tax rates and other Government Regulations.

This was done to adjust to the level of social and economic life of the Indonesian people as well as the pace of national development that had been achieved. In addition, the old taxation system has not been able to move the role of all layers of tax subjects whose role is to produce domestic revenues that are needed to realize the sustainability and increase of national development.

Taxation is not enough just to be known, but it must be understood and comprehensively understood from the aspects of tax law, the basis of taxation, taxation, tax disputes, and taxpayer rights. Therefore, the Directorate General of Tax (DGT) of the Ministry of Finance encourages understanding of tax among students, because students are considered to have a strategic role in boosting future tax revenues that are prospective workers. As prospective workers or employers, understanding students is not enough in terms of theory alone. Taxation is one of the fields of science that is easier to understand with real accounting practices.

The development of tax practicum teaching materials is one of the efforts made to be able to improve the practicum ability of students because taxation is one of the fields of science that is not sufficiently studied from the theoretical side only, but taxation is easier to understand with real bookkeeping practice, so that the competencies possessed by students are able to answering the needs of stakeholders and not experiencing lag in terms of the latest tax regulations. For the lecturers that responsible for practicum, an important task that must and needs to be done is to design and manage a practicum activity so that the instructional objectives are clear, the contents and sequence of activities are well directed, relevant to the demands graduate professional assignments later and are designed in such a way as to be an interesting and enjoyable learning experience for students, not just torture and boring instead [1].

Competence of tax practicum courses is to produce students who are able to understand taxation provisions, calculate taxes, do reporting and complete tax administration completeness, filling annual tax returns for individuals and entities. This taxation practicum will train cognitive and affective skills. In cognitive skills students can train themselves so that theories can be understood and various theories can be integrated and can apply theories to real situations through the practice of solving taxation cases. Affective skills aim to enable students to learn and to plan activities independently and in collaboration. These skills are needed to realize the competency of tax practicum subjects.

Based on the problems and findings above, it is necessary to compile a teaching material that is able to integrate practice skills and taxation theory, so that it can help students to play an active role in the learning process and the level of thinking is not only at the remembering, memorizing, and students are more fluent and able to make and resolve tax cases properly. For this reason, researchers wanting to develop teaching materials on tax practice must adjust the latest tax regulations and raise the latest tax issues and adjust them to graduate competencies. It is expected to ultimately produce graduates who are competent in the field of taxation and in accordance with stakeholder needs.

\section{Literature Review}

Teaching materials are media and learning resources, which have a strategic position because teaching materials prepare guidelines for students both for the benefit of independent learning and in scheduled face-to-face activities, also equipped with methods and evaluations, and guidelines for students. Good teaching materials are: (1) can arouse student interest in 
learning, (2) have a clear purpose instructional, (3) present material with a good structure, (4) provide opportunities for students to practice and provide feedback to students, and (5) create two-way communication [2]. In addition to the above to stimulate student creativity and interest in learning, teaching materials are designed as attractive as possible including the use of colors, shapes, font sizes and thickening of letters, boxing and lines are also needed to clarify the message content. Tax is the main legal field. The tax issue is a matter of the state which means that it concerns all the people residing in the territory of the Republic of Indonesia. Tax law has recently been transformed into a separate branch of science which means that tax law is a source of inspiration both scientific and popular. In connection with changes in the structure of society, Indonesian taxation law undergoes changes and is adapted to a new spirit or reformation spirit in the era of globalization, therefore Indonesian taxation law is not only important for education but also needs special attention from the people's leaders and politicians.

The impact of globalization, increasing the competitiveness of nations and adjustment to the economic level of Indonesian people cause changes in laws or taxation cases. This means that the way taxes are regulated must be adjusted to the needs of the community as a reaction to changes in the economic life of the community itself.

This research is a research and development or Research and Development (R\&D). The development carried out in the form of Tax Practicum Teaching Materials. Development of Tax Practicum Teaching Materials follows the Dick and Carey Model. If the ten steps of the Dick \& Carey development model and follow the stages of developing instructional media properly, it will be able to produce an educational product that can be accounted for.

\section{Development of Subjects for Tax Practicum Subjects}

This research is a research and development $(\mathrm{R} \& \mathrm{D})$ type. The development carried out in the form of Tax Practicum Teaching Materials. Development of Tax Practicum Teaching Materials follows the Dick and Carey Model. If the ten steps of the Dick \& Carey development model and follow the stages of developing instructional media properly, it will be able to produce an educational product that can be accounted for. The ten steps of developing the Dick \& Carey teaching material model are described as follows.

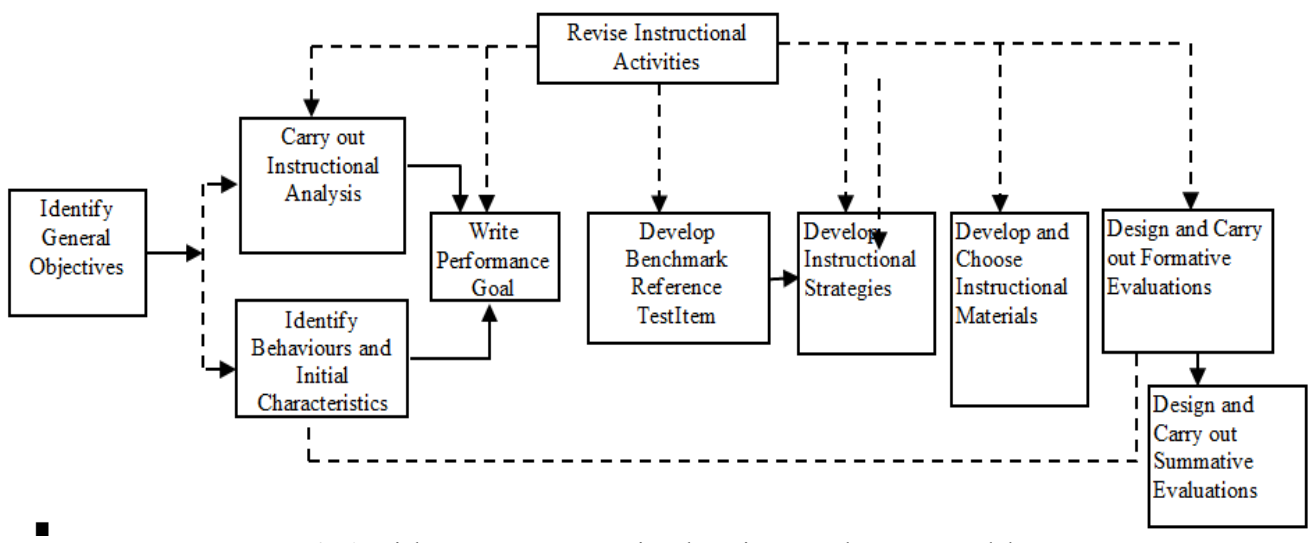

Fig 1. Dick \& Carey's Instructional Design Development Model

Information: : stage line feedback and revision lines 
These steps are not standard things that to be followed, the steps taken can be adjusted to the needs of researchers. To produce interactive learning products that have good planning, learning design is needed.

\section{Research Methods}

This research was conducted at the Faculty of Economics, Universitas Negeri Medan in the odd semester of the 2019/2020 school year for students taking taxation practicum courses. At the development stage of learning media, targeting in this case are lecturers, instructional media experts, instructional design experts, subject matter experts and students who assess learning media that have been developed based on the criteria, as follows: (I) evaluators are based on the expertise they have, (2) evaluators who carry out evaluations are determined based on the ability of practitioners / lecturers with the classification of experts in the field of study. Assessments are also obtained from students for the response to the use of teaching material that was developed. The development of learning strategies and teaching materials in this study uses a development model adopted from Dick, Carey [3]. The stages of development implementation consist of: 1) Pre-Development 2) Development of teaching materials and learning strategies 3) Product reviews and trials 4) Processing and analysis of data and application of learning strategies and teaching materials[5,6].

Analysis of the data of this study uses quantitative descriptive analysis. All data collected were analyzed using descriptive statistical techniques that were separated quantitatively by categories to sharpen the judgment in drawing conclusions. This analysis is intended to describe the characteristics of the data in each variable and will make it easier to understand the data for the subsequent analysis process. Qualitative data in the form of statements that are not feasible, less feasible, and feasible are converted into quantitative data with a rating scale of 1 to 4. Data analyzed using trial analysis with quantitative analysis using Gain scores[7]. The trial results consist of objective test consisting of pre-test and post-test scores.

\section{Results and Discussion}

This research and development aims to produce taxable teaching materials that are in accordance with the latest tax regulations. The development of learning strategies and teaching materials in this study uses a development model adopted from Dick and Carey. The stages of development implementation consist of: a) Pre-Development b) Development of teaching materials and learning strategies c) Review and trial of products and development of teaching materials; and d) data processing and analysis stage.

Test the effectiveness of the material experts include aspects of the feasibility of the content, the feasibility of language, and the feasibility of graphic. The feasibility test process is carried out to find out whether the material presented in teaching materials is in accordance with the competency standards and basic competencies of taxation subjects and semester learning plans, the language used is easy to understand and graphics / tables are in accordance with the subject matter. Average total assessment from experts this learning material obtained $83.33 \%$ results. In accordance with the percentage scale, the results fall into the quite feasible / attractive / motivated category.

Test the effectiveness of media design experts Learning aims to get input and advice on the design of tax practicum textbooks in developing tax practicum teaching materials in 
accordance with the latest tax regulations that are generally accepted in Indonesia in order to increase understanding of concepts / materials and mastery of tax practices in making / producing the company's annual tax report on the tax practicum course at the Universitas Negeri Medan Faculty of Economics accounting study program. The average total rating of the learning design expert on the taxation practicum textbook design was $80 \%$. In accordance with the percentage scale, the results fall into the quite feasible / attractive / motivated category.

The effectiveness test of instructional media experts includes aspects of non-visual communication that can lead to mutual benefits so that they are able to solve a problem because teaching materials are central to the development of knowledge of understanding a material / concept for students. The average total rating of the instructional design expert on the design of textbooks with solving this problem obtained $79,16 \%$. In accordance with the percentage scale, the results fall into the sufficient / attractive / motivated category to be used.

After the product of teaching material is tested its effectiveness by material experts, design experts and media experts, it is then revised according to the suggestions or comments of the validators. The revised product then enters the student trial phase as the end product user. Teaching materials developed were tested on 6 students called small groups representing accounting students in the second semester who took taxation practicum courses with the criteria of 2 high, medium and low ability students respectively. The assessment aspects given in small group trials include aspects of content eligibility, graphic aspects, and aspects of benefits. The average total assessment of students in the small group test on the design of this taxation practicum textbook obtained $82.23 \%$ results. In accordance with the percentage scale in table 4.1, the results fall into the "quite feasible / interesting / motivated" category.

The assessment aspects of small and large group tests for students are also carried out by holding pre-test and post-test. The mean / mean pre-test score of the small group was 5.83, and the mean / post-test mean score was 8.33, or an increase of 2.5. This means that the use of the product materials development results can improve the scores of students by $25 \%$ da $\mathrm{n}$ average / mean scores of pre-test a large group was 5.61, and the average / mean score of post-test is 8.34 , or an increase of 2.72 . This means that the use of teaching material products developed results can increase student scores by $27.2 \%$. While the results of the assessment on the questionnaire according to the small group about the design of this taxation practicum textbook obtained $82.23 \%$ results and the large group obtained $84.57 \%$ results. In accordance with the percentage scale, the results fall into the quite feasible / interesting / motivated category.

\section{Acknowledgements}

From year to year, revenue from the tax sector continues to show an increase. In the context of efforts to increase tax revenue, the government made a fundamental change by creating a new taxation system, namely by changing the new taxation law. This was done to adjust to the level of social and economic life of the Indonesian people as well as the pace of national development that had been achieved. 


\section{References}

[1] Zainuddin M. Practicum. PAU PPAI. Directorate General of Higher Education. Ministry of National Education. Jakarta. (2001).

[2] Wadjdi, Faried. Effect of Material BelajarTerhadap Learning Outcomes On Currency Kulia h Series of Basic Electricity (A Study on the Electrical Engineering Department UNJ). Journal of Engineering. (2014).

[3] Whening. Development of Biology Science Package for Class VIII SMPLB-B Using the Dick Carey \& Carey Model. JRR. (2016).

[4] Pannen, Paulina, et al. Constructivism in Learning. PAU PPAI. Directorate General of Higher Education. Ministry of National Education. Jakarta. (2001).

[5] Pannen, Paulina and Purwanto. Writing Teaching Materials. PAU PPAI. Directorate General of Higher Education. Ministry of National Education. Jakarta. (2001).

[6] Prastowo, Andi. Creative Guide to Making Innovative Teaching Materials. Yogyakarta: Diva Press. (2012).

[7] Widyaningrum, Ratna, Sarwanto, Karyanto, Puguh. Development of POE Oriented Module (Predict, Observe, Explain) with Environmental Insight on Pollution Material to Improve Student Learning Outcomes. Bioeducation. Surakarta (2013). 